\title{
Exudate coloring test suitability for assessing the viability of coffee seeds (Coffea arabica L.) ${ }^{1}$
}

\author{
Paulo César Hilst ${ }^{2}$, Denise Cunha Fernandes dos Santos Dias ${ }^{2}$, \\ Guilherme Fontes Valory Gama², Joyce de Oliveira Araújo ${ }^{2}$
}

\begin{abstract}
The exudate coloring test has been promising in order to quickly evaluate the quality of coffee seeds. The objective of the research was to adjust the coloring exudate test for coffee seeds and to evaluate the influence of the water content of seeds and of the imbibition period on the test results. Seeds from five lots of 'Catuaí 44' were used, with the following water contents: $30 \%, 20 \%$ and $12 \%$. For the exudate coloring test, the parchment and silver skin (spermoderm) from the seeds were removed. Then, the seeds were distributed on a paper towel, moistened with water, and kept in a germinator at $25^{\circ} \mathrm{C}$ for $24,48,72,96$ and $120 \mathrm{~h}$. Four classes of coloring intensity were established: absence of color (A), light (L), medium (M) and strong (S) intensities, assigning the values $0,3,5$ and 10 for each class, respectively. The Viability Index (VI) was calculated by the equation $\mathrm{VI}=100-(0 \mathrm{xA})-(3 \mathrm{xL})-(5 \mathrm{xM})-(10 \mathrm{xS})$. The exudate coloring test may be recommended to estimate the viability of coffee seeds, providing results correlated to the germination test. The best results were obtained for the seeds with $12 \%$ moisture content imbibed for 72,96 and $120 \mathrm{~h}$ and seeds with $30 \%$ moisture content after 72 and $120 \mathrm{~h}$ of imbibition.
\end{abstract}

Index terms: lixiviates, color, physiological quality, Coffea arabica $\mathrm{L}$.

\section{Adequação do teste de coloração de exsudatos para avaliação da viabilidade de sementes de café (Coffea arabica L.)}

\begin{abstract}
RESUMO - O teste de coloração do exsudato tem se mostrado promissor para a avaliação rápida da qualidade de sementes de café. Assim objetivou-se adequar a metodologia deste teste verificando a interferência do teor de água das sementes e do período de embebição nos resultados. Foram utilizadas sementes de cinco lotes de 'Catuaí 44', com teores de água de 30\%, 20\% e 12\%. Para o teste de coloração de exsudatos, foram retirados o pergaminho e a película prateada (espermoderma) das sementes, em seguida foram distribuídas sobre papel toalha umedecido com água e mantidas a $25^{\circ} \mathrm{C}$ por $24,48,72,96$ e $120 \mathrm{~h}$. Foram estabelecidas quatro classes de intensidade de coloração: ausência de coloração (A), intensidades de coloração leve (L), média (M) e forte (F), atribuindo-se os valores 0, 3, 5 e 10, para cada classe, respectivamente, calculando-se o Índice de Viabilidade por meio da equação IV=100-(0xA)$(3 \mathrm{xL})-(5 \mathrm{xM})-(10 \mathrm{xF}) . \mathrm{O}$ teste de coloração do exsudato pode ser utilizado para estimar a viabilidade de sementes de café, fornecendo resultados correlacionados aos do teste de germinação. Resultados mais promissores foram obtidos com sementes com $12 \%$ de umidade após 72, 96 e 120 h de embebição e com 30\% de umidade após 72 e 120 h de embebição.
\end{abstract}

Termos para indexação: lixiviado, cor, qualidade fisiológica, Coffea arabica L.

\section{Introduction}

Coffee seeds have a slow and irregular germination, even under favorable conditions. Even by removing the endocarp or parchment, the germination of these seeds, under ideal conditions in the laboratory, demands a period of at least 30 days (Brasil, 2009). Therefore, the germination test results may no longer reflect the actual physiological condition of the seeds, since they lose their viability within a short term.
Therefore, it is fundamental to use quick tests in order to evaluate the physiological quality of these seeds, in order to support the decision-making process related to the postharvest management and the commercialization of lots.

The tests that demand less time to be conducted are related to enzymatic and respiratory activities of the seeds or to the integrity of the cellular membranes (Marcos-Filho, $2015 b$ ). The loss of the selective permeability of the cellular membranes has been reported as one of the initial events of

${ }^{1}$ Submitted on 04/23/2016. Accepted for publication on 07/19/2016.

${ }^{2}$ Departamento de Fitotecnia, Universidade Federal de Viçosa, 36570-900 - Viçosa, MG, Brasil.

*Corresponding author < pchilst@yahoo.com.br>

Journal of Seed Science, v.38 n.3, p.212-218, 2016 
the deterioration process of seeds, which culminates with the loss of the germination power (Marcos-Filho, 2015a).

As the seeds dry, the cellular membranes undergo a process of structural disorganization, and the lower the water content on the seed, the more disorganized they get, temporarily losing their organizational integrity (Bewley et al., 2013). Therefore, during the initial stage of imbibition of the seeds, until the membranes are reorganized, a quick leaching of exudates occurs (Marcos- Filho, 2015a). The speed and the intensity according to which the exudates are released depend directly on the state of organization of the system of cellular membranes. Deteriorated or less vigorous seeds usually release a larger amount of exudates due to the disruption of their membranes (Milosevic et al., 2010). Among the quick tests that are based on the integrity of the system of cellular membranes and that have been studied for coffee seeds, some highlights are the electrical conductivity test (Costa and Carvalho, 2006; Soto et al., 1995; Malta et al., 2005), pH exudate (Vieira et al., 1998), Lercafé (Zonta et al., 2008; Reis et al., 2010), and the exudate coloring test (Sera and Miglioranza, 2000; Sera et al., 2006; Hilst et al., 2012).

The exudate coloring test was initially suggested by Sera and Miglioranza (2000), when they observed that lowerquality coffee seeds exuded substances with a brown color, at different intensities, when soaked on a moistened paper towel with water, attributing grades to the presence and absence of brown exudate. This methodology was improved by Hilst et al. (2012), classifying the coloration of exudates into three categories: absence of coloring, light and strong coloring, which allowed the distinction of lots of high and low physiological quality 24 hours after the seeds had been imbibed on a paper soaked with water. However, the authors reported that, for a more efficient separation of the lots into quality levels, studies would be necessary in order to adjust the evaluation criteria.

On tests based on the release of exudates by the seeds, several factors may affect the leaching intensity of solutes and, consequently, the results; some of these factors are the quality of the water, the temperature and duration of the imbibition period, the water content and the number of tested seeds, the presence of mechanical damage or damages caused by insects, and the size of the seed (Dias and Marcos-Filho, 1996).

Among the factors mentioned, the water content of the seeds and the imbibition period during the conduction of the test deserve special attention. Considering that coffee seeds are commercialized with variable water contents, up to approximately $30 \%$, and since the organization of the membrane system is directly related to the water content of the seeds (Marcos-Filho, 2015b), this factor may influence the quantity of exudates released by the seeds.
Therefore, information related to the methodology and applicability of the exudate coloring test for coffee seeds, as well as its adequacy for application in commercial lots, is an important factor for the coffee seeds production industry. It is noteworthy that this is a non-destructive method to evaluate the quality of the seeds, which makes it rather interesting.

The aim of this study was to improve the conduction methodology and the evaluation criteria of the exudate coloring test on coffee seeds with different humidity degrees.

\section{Material and Methods}

The research was conducted at the Laboratory of Seeds from the Plant Science Department of the Federal University of Viçosa. Five lots of 'Catuaí 44' coffee seeds we used (Coffea arabica L.), produced in Viçosa, MG. The fruits, harvested during the cherry stage, had their pulp removed; the seeds were dried in the shade at environmental condition until they reached water contents of approximately $30 \%, 20 \%$ and $12 \%$.

The quality of the seeds from each lot were evaluated by the following tests:

Seed moisture content: the oven method was used at 105 $\pm 3{ }^{\circ} \mathrm{C}$, with two subsamples of 30 seeds per treatment, after the removal of the parchment (Brasil, 2009). The results were expressed as a percentage.

Germination: conducted with four subsamples of 50 seeds (without the parchment) on moistened paper towel rolls with water volume equivalent to 2.5 times the weight of the dry paper in a germinator at $30{ }^{\circ} \mathrm{C}$ (Brasil, 2009). The evaluations were conducted 21 and 30 days after the sowing, and the results were expressed as a mean percentage of normal seedlings.

Germination at first count: consisting of the percentage of normal seedlings obtained 21 days after the sowing of the germination test described above.

Accelerated aging: approximately 250 seeds with no parchment were distributed on the aluminum screen connected to the gerbox boxes, containing, on the bottom, $40 \mathrm{~mL}$ of distilled water. The closed boxes were maintained on B.O.D. at $45^{\circ} \mathrm{C}$, for 72 hours, as described by Hilst et al. (2012). After this period, four subsamples with 50 seeds were placed to germinate as described above for the germination test (Brasil, 2009), evaluating the mean percentage of normal seedlings obtained 21 days after sowing.

Exudate coloring test: the methodology described by Hilst et al. (2012) was used. Four subsamples of 10 seeds without the parchment were soaked in water for 10 minutes, in order to remove the silver skin (spermoderm). Then, the seeds were arranged on three paper towel sheets moistened with water at a proportion of three times the weight of the dry paper, arranged on aluminum screens connected to gerbox boxes, containing, 
on the bottom, $40 \mathrm{~mL}$ of water. The closed boxes were kept on a germinator at $25^{\circ} \mathrm{C}$ for $24,48,72,96$ and $120 \mathrm{~h}$. After each period, the visual evaluation of the coloring intensity of the exudate created on the bottom of each seed was conducted, establishing four coloration classes, as illustrated on Figure 1: absence of coloration, light coloration intensity, medium coloration intensity, and strong coloration intensity, assigning grades of $0,3,5$ and 10 , respectively for each class. The number of seeds obtained for each exudate coloration class was multiplied by the grade corresponding to each class, and the sum obtained for the four classes was subtracted from 100 (considered as the maximum viability value, that is, 100\%), thus, establishing the Viability Index (VI) of the seeds (\%), calculated as follows:

$\mathrm{VI}=100-[(\mathrm{A} \times 0)+(\mathrm{L} \times 3)+(\mathrm{M} \times 5)+(10 \times \mathrm{S})]$, where:

VI is the Viability Index of the seeds (\%);

$\mathrm{A}$ is the number of seeds with absence of coloration;

$\mathrm{L}$ is the number of seeds that originated a light coloration intensity;

$\mathrm{M}$ is the number of seeds that originated a medium coloration intensity;

$\mathrm{S}$ is the number of seeds that originated a strong coloration intensity.

From the VI values obtained for each replication, the mean for each lot was calculated.

At the end of the last evaluation of the exudate coloring test $(120 \mathrm{~h})$, each duly identified seed was placed to germinate as described above for the germination test. For each seed placed to germinate, an attempt was made to relate the exudate coloration produced by the seed and the result obtained on the germination test (normal or abnormal seedling or dead seed).

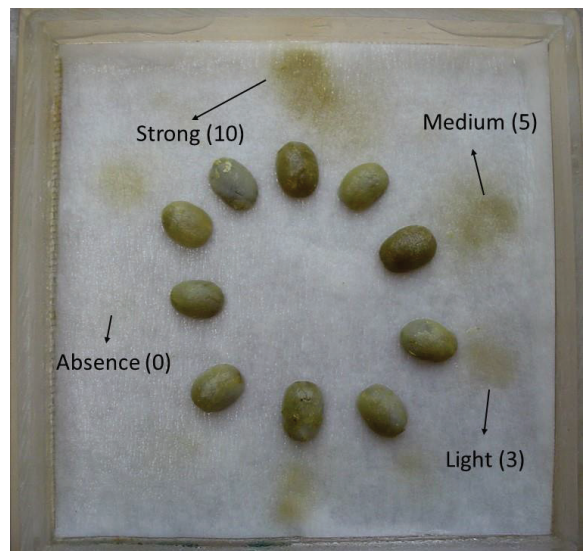

Figure 1. Illustration of the coloring intensities of the exudate of each seed, assigning values of $0,3,5$ and 10 , for the absence of coloring, light, medium and strong coloring, respectively.

\section{Statistical procedure:}

The experiment was installed under a completely randomized design with four replications. The analysis of variance was conducted under a factorial of $(5 \times 3)$, with 5 lots $\mathrm{x} 3$ water contents of the seeds. For the qualitative factors, the comparison among the means was conducted according to Tukey's test at $5 \%$ of probability. The Pearson coefficient correlations (r) were calculated, regarding the Viability Index obtained on the exudate coloring test and the other tests used to evaluate the physiological quality of the seeds; the significance of the $r$ values was determined by the $t$ test, at 1 and $5 \%$ of probability.

\section{Results and Discussion}

For coffee seeds with $12 \%$ of water content (Figure $2 \mathrm{~A}$ ), it was observed that the germination of lots 1 and 4 was higher than the one for lots 3 and 5. Lots 1 and 4 also stood out regarding their vigor, mainly when compared to lots 3 and 5, according to the germination first counting and the accelerated aging tests. In general, the seeds from lot 5 with water content of $30 \%$ (Figure $2 \mathrm{C}$ ) were significantly inferior to the seeds from the other lots according to the germination, first counting, and accelerated aging test. When seeds with water content of $20 \%$ were used (Figure 2B), only by using the accelerated aging test it was possible to observe significant differences among the lots, considering that lots 2 and 4 were superior in relation to the other ones. In general, even with some variations depending on the test used and the water content of the seeds, a tendency for a better and worse performance for the seeds of lots 4 and 5, respectively, may be highlighted.

The viability indexes (VI) of the seeds calculated based on the exudate coloring test results (Figure $3 \mathrm{~A}$ ) conducted with seeds with $12 \%$ moisture content and imbibed for 72,96 and $120 \mathrm{~h}$, indicate a better physiological quality for lots 1 and 4 , and lower quality for lots 2, 3 and 5, which did not differ from one another. It is observed that with $24 \mathrm{~h}$ of imbibition, lots 1 and 4 were also classified as better quality lots, although, during this period, lot 1 did not differ significantly from lot 5 , which, in turn, was similar to the lower quality lots (lots 2 and 3). Within the period of $48 \mathrm{~h}$, a better performance was observed also for lots 1 and 4, and a worse performance for lot 2 ; lot 5 remained on an intermediate position.

For seeds with $20 \%$ moisture content, similarly to what was observed on the germination, first count and emergence tests (Figure 2B), also for the exudate coloring test, it was not possible to detect a significant difference among the quality 
of the five studied lots (Figure 3B). It is observed by the accelerated aging test (Figure 2B), that the seeds from lots 2
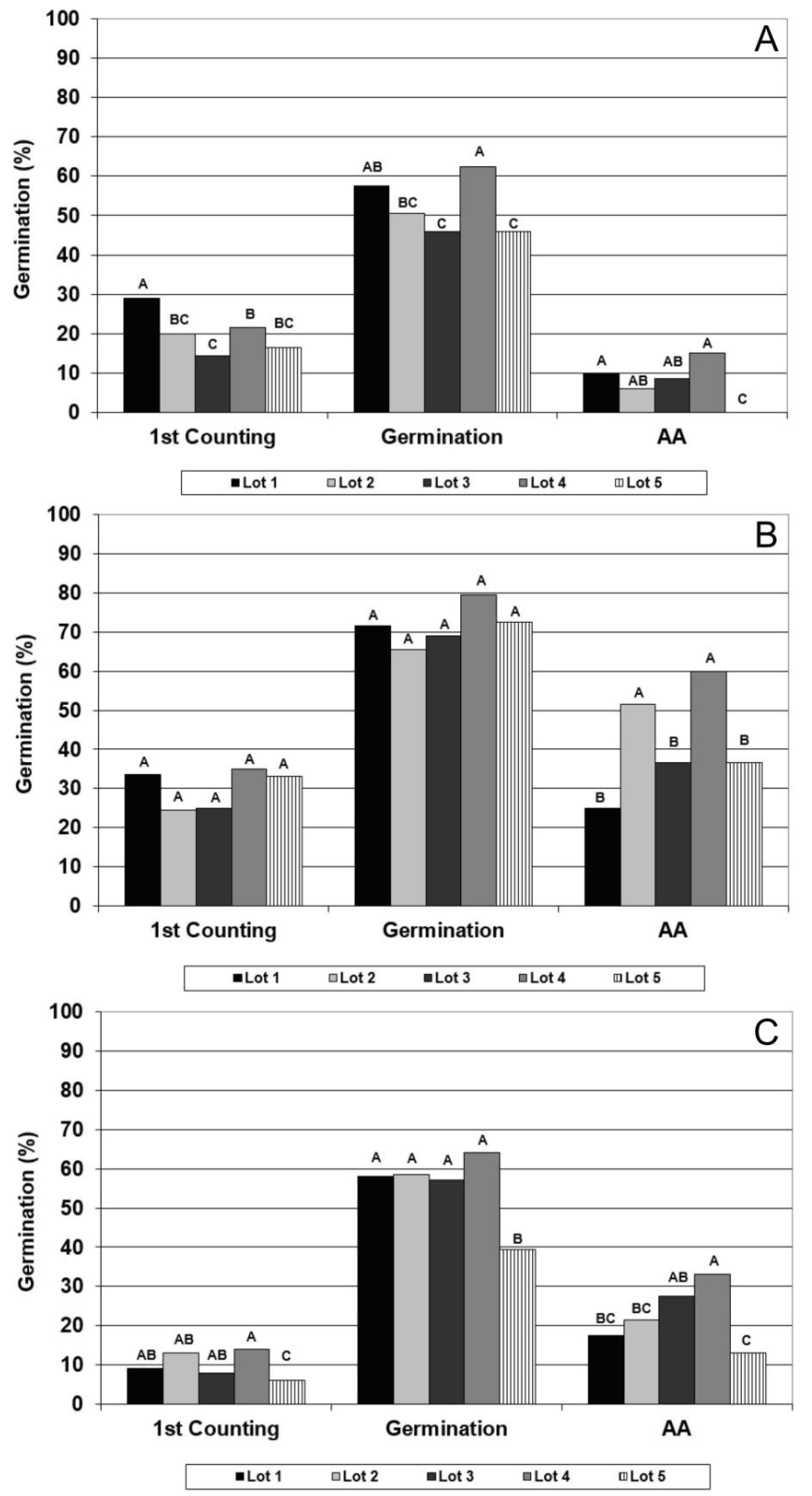

Figure 2. Normal seedlings obtained on the germination, first counting and accelerated aging (AA) tests from five lots of coffee seeds with water contents of $12 \%$ (A), 20\% (B) and 30\% (C). Means followed by the same letter are not statistically different according to Tukey's test $(\mathrm{p}<0.05)$.

On the other hand, for seeds with 30\% water content (Figure $3 \mathrm{C})$, there was a significant difference among the lots in all imbibition periods; in general, the seeds from lot 5 had lower and 4 were superior to the ones from the other lots, which was not observed on the exudate coloring test (Figure 3B).
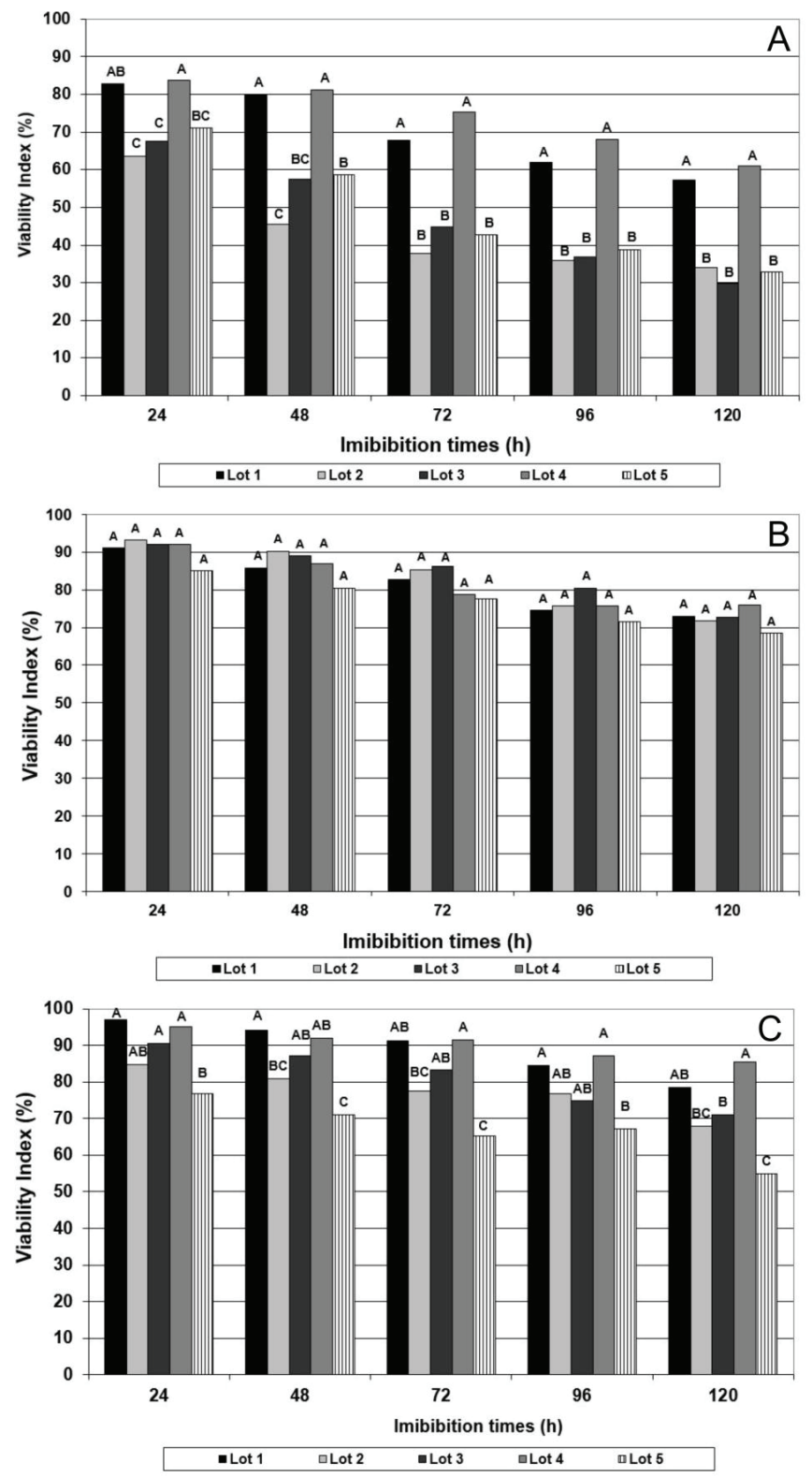

Figure 3. Viability Index of the seeds from five coffee lots with water contents of $12 \%$ (A), $20 \%$ (B) and $30 \%(\mathrm{C})$, after different imbibition times. Means followed by the same letter, within each imbibition time, are not statistically different according to Tukey's test $(\mathrm{p}<0.05)$.

VIs, mainly in relation to the ones obtained for lots 1, 3 and 4.

Comparing the VIs to the results obtained on the other tests to evaluate the physiological quality of the seeds (Figure 
2 ), it may be stated that, in general, there was an agreement as to the higher quality of the seeds from lot 4 and the lower quality of the seeds from lot 5 , on most conducted tests. In general, the most promising results were obtained with seeds with $12 \%$ moisture content after imbibition periods of 72,96 and $120 \mathrm{~h}$ (Figure $3 \mathrm{~A}$ ), and with seeds with $30 \%$ of water after 72 and $120 \mathrm{~h}$ (Figure 3B).

On Figures 4, 5 and 6, it is possible to observe differences on the coloration intensity of the exudates of the seeds from five lots with water content of $12 \%, 20 \%$ and $30 \%$, and their respective VIs, after $120 \mathrm{~h}$ of imbibition. The lots with the highest VIs, such as lot 4, showed less evident coloration intensities, while lots with the lowest VIs, such as lots 2, 3 and 5, showed a higher

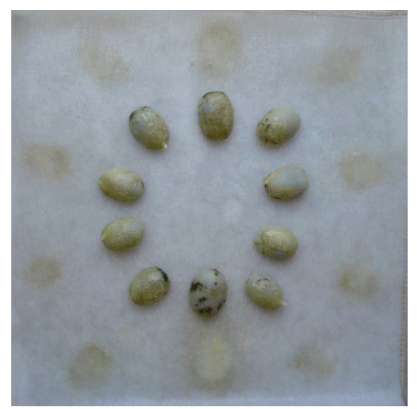

Lot $1(\mathrm{VI}=57 \%)$

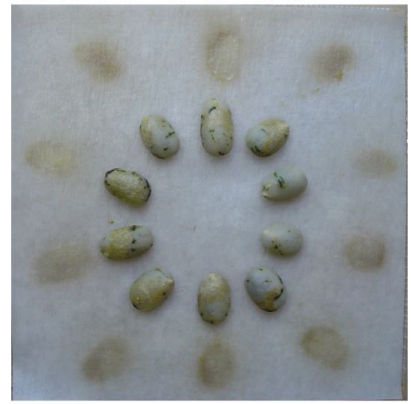

Lot $3(\mathrm{VI}=30 \%)$

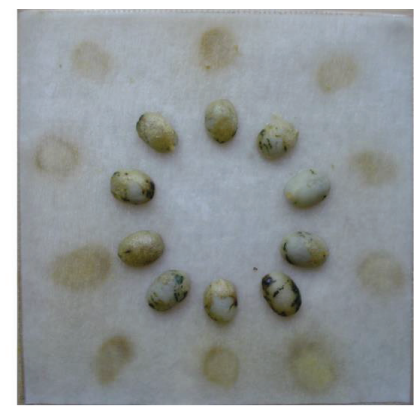

Lot $2(\mathrm{VI}=34 \%)$

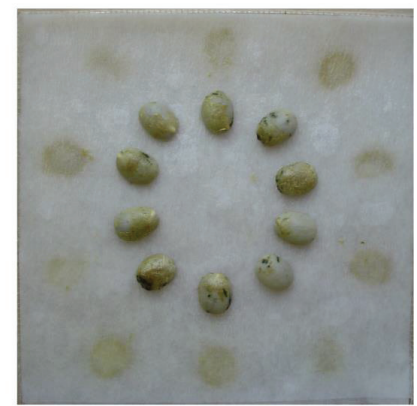

Lot $4(\mathrm{VI}=61 \%)$

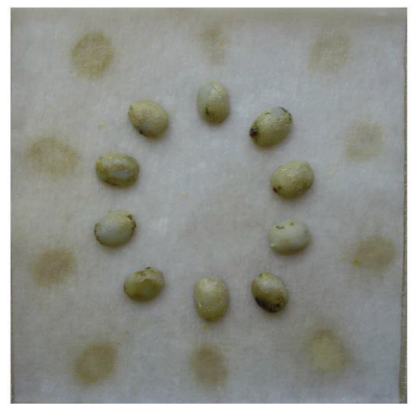

Lot $5(\mathrm{VI}=33 \%)$

Figure 4. Illustrations of the coloring of exudates obtained during the evaluation of five lots, with seeds with water contents of $12 \%$, after 120 hours of imbibition, and their respective Viability Indexes (VI). number of seeds with stronger coloration intensity.

Comparing the tonalities of the exudates obtained from the seeds with different water contents (Figures 4, 5 and 6), a better differentiation is observed for those with $12 \%$ moisture content, which show clearer differences among the strong, medium and light intensities in relation to the others. According to the results of the germination and vigor tests (Figures 2A and 2C) and the VIs (Figures 3A and 3C), it was possible to observe that there was a separation among the lots as to their physiological quality when seeds with $12 \%$ and 30\% moisture content were used, respectively, which did not occur on the tests conducted with seeds with $20 \%$ water content (Figures 2C and 3B).

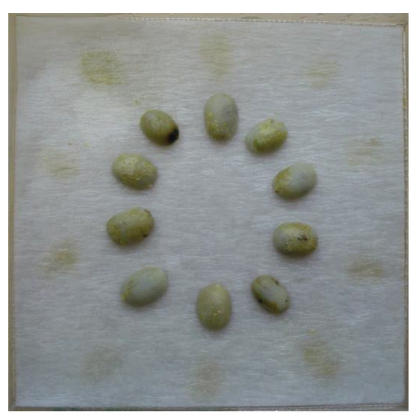

Lot $1(\mathrm{VI}=73 \%)$

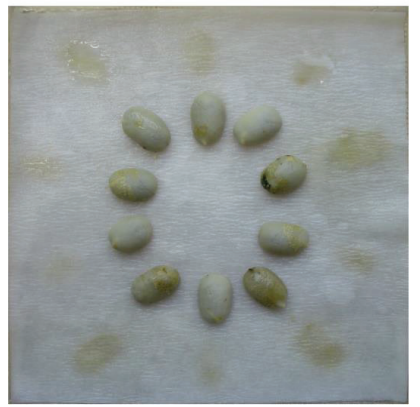

Lot $3(\mathrm{VI}=73 \%)$

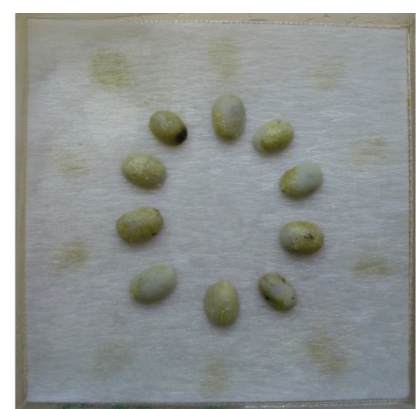

Lot $2(\mathrm{VI}=72 \%)$

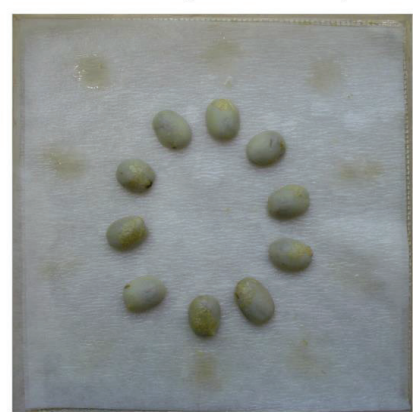

Lot $4(\mathrm{VI}=76 \%)$

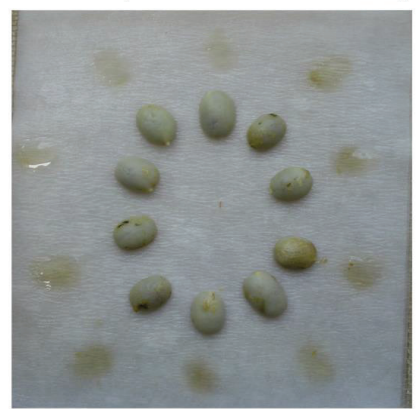

Lot $5(\mathrm{VI}=69 \%)$

Figure 5. Illustrations of the coloring of exudates obtained during the evaluation of five lots, with seeds with water contents of $20 \%$, after 120 hours of imbibition, and their respective Viability Indexes (VI). 


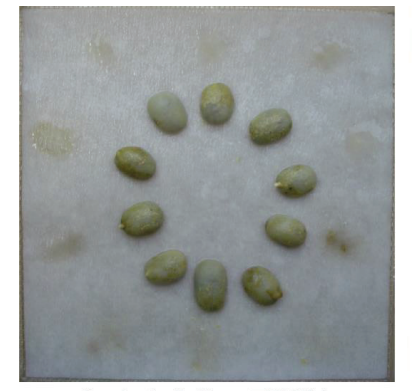

Lot $1(\mathrm{VI}=79 \%)$

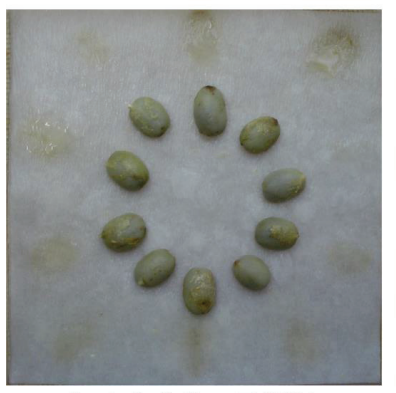

Lot $3(\mathrm{VI}=71 \%)$

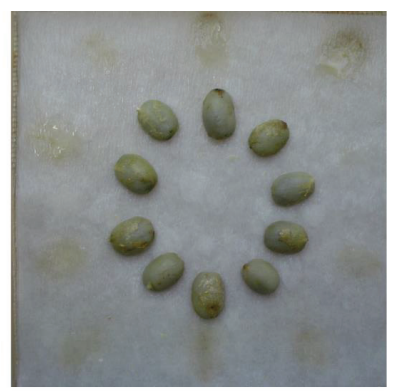

Lot $2(\mathrm{VI}=68 \%)$

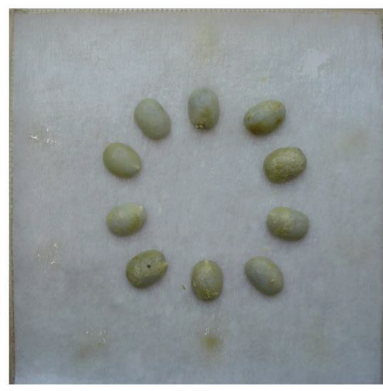

Lot $4(\mathrm{VI}=86 \%)$

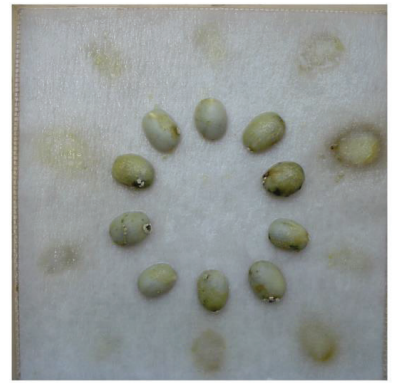

Lot $5(\mathrm{VI}=55 \%)$

Figure 6. Illustrations of the coloring of exudates obtained during the evaluation of five lots, with seeds with water contents of $30 \%$, after 120 hours of imbibition, and their respective Viability Indexes (VI).
It is important to point out that, although the results of the exudate test both for seeds with 12 and $30 \%$ of water, have been promising, it was observed that it was easier to interpret and distinguish the intensities of the exudates when dry seeds were used ( $12 \%$ water content). This fact may be attributed to the fact that seeds with higher water contents $(30 \%)$ undergo a lower leaching, offering a less evident coloring intensity. Totally or partially hydrated seeds showed a lower leaching of solutes when under imbibition, due to the quicker structuring of the cellular membranes when compared to dry seeds (Bewley and Black, 1994).

Table 1 shows the correlation coefficients among the imbibition periods of the exudate coloration test and the other tests conducted. For seeds with $12 \%$ moisture content, there was a significant correlation among the results of the exudate coloration test on the periods of 72, 96 and 120 hours of imbibition and the ones from the germination test, indicating that the new test suggested offers results that are associated to the germination results, and they may be used to estimate the viability of coffee seeds within a reduced time period than the one that is necessary to conduct the germination test, of at least 30 days. This is an important aspect for the decision making regarding the destination of the lots right after harvesting, during processing, storage and commercialization. For seeds with $20 \%$ moisture content, there was no significant correlation between the results of the exudate coloring test and the germination test, reinforcing the results shown on Figures 2 and 5 . When seeds with $30 \%$ water were used, highly significant correlations were observed between the germination and VI results conducted for 72 and 120 hours, indicating that, for seeds with high water contents, the exudate coloring test may be used to estimate the viability.

Table 1. Simple correlation coefficients (r) across the results of the germination (Germ), germination first count (1 $1^{\text {st }}$ Count), accelerated aging (AA) tests, and the results obtained on the exudate coloration tests (Exd) after 24, 48, 72, 96 and 120 hours of imbibition, conducted with seeds with water contents of $12 \%, 20 \%$ and $30 \%$.

\begin{tabular}{ccccccccc}
\hline & \multicolumn{7}{c}{$12 \%$ of water } \\
\hline Germ & Germ & 1 st Count & AA & Exd 24 & Exd 48 & Exd 72 & Exd 96 & Exd 120 \\
1st Count & 1.00 & 0.75 & 0.83 & 0.85 & 0.80 & $0.91 *$ & $0.95 *$ & $0.97 * *$ \\
AA & - & 1.00 & 0.53 & 0.67 & 0.63 & 0.67 & 0.72 & 0.79 \\
\hline & - & - & 1.00 & 0.65 & 0.67 & 0.80 & 0.77 & 0.76 \\
\hline Germ & 1.00 & 0.85 & 0.33 & 0.18 & 0.40 & 0.76 & 0.25 & 0.50 \\
1 st Count & - & 1.00 & 0.04 & 0.44 & 0.67 & 0.84 & 0.62 & 0.18 \\
AA & - & - & 1.00 & 0.36 & 0.35 & 0.22 & 0.06 & 0.48 \\
\hline & & & & $30 \%$ of water & & & & 0.90 \\
\hline Germ & 1.00 & 0.80 & 0.79 & 0.84 & 0.86 & $0.90 * *$ & 0.87 & 0.67 \\
1 st Count & - & 1.00 & 0.67 & 0.44 & 0.47 & 0.57 & 0.69 & 0.73 \\
AA & - & - & 1.00 & 0.59 & 0.59 & 0.66 & 0.59 & \\
\hline
\end{tabular}

$*$, ** significant at $5 \%$ and $1 \%$ of probability according to the $t$ test. 
It is important to consider that, in order to conduct the exudate coloring test, no specific equipment and materials are necessary in addition to the ones that are traditionally used to conduct the germination test, which makes this a promising test, since it allows the quick evaluation of the viability of coffee seeds.

\section{Conclusions}

The exudate coloring test is promising for the quick evaluation of the viability of coffee seeds, especially when conducted with seeds with $12 \%$ moisture content, after imbibition periods of 72,96 or 120 hours. Seeds with $30 \%$ moisture content after imbibition for 72 or 120 hours may also be used.

\section{References}

BEWLEY, J.D.; BLACK, M. Seeds - Physiology of development and germination. 2.ed. New York: Plenum Press, 1994. 445 p.

BEWLEY, J.D.; BRADFORD, K.J.; HILHORST, H.W.M.; NONOGAKI, H. Seeds- Physiology of development, germination and dormancy. 3.ed. New York: Springer, 2013. 392p.

BRASIL. Ministério da Agricultura, Pecuária e Abastecimento. Regras para análise de sementes. Ministério da Agricultura, Pecuária e Abastecimento. Secretaria de Defesa Agropecuária. Brasília, DF: MAPA/ACS, 2009. 395p. http://www.agricultura.gov.br/arq_editor/file/2946_regras_analise_ sementes.pdf

COSTA, P.S.C.; CARVALHO, M.L.M. Teste de condutividade elétrica individual na avaliação da qualidade fisiológica de sementes de café (Coffea arabica L.). Ciência e Agrotecnologia, v.30, n.1, p.92-96, 2006. http://www. scielo.br/scielo.php?pid=S1413-70542006000100013\&script=sci_arttext

DIAS, D.C.F.S.; MARCOS-FILHO, J. Testes de condutividade elétrica para avaliação do vigor de sementes de soja (Glycine max (L.) Merrill). Scientia Agricola, v.53, n.1, p.31-42, 1996. http://www.scielo.br/scielo. php?pid=S0103-90161996000100005\&script=sci_arttext

HILST, P.C.; DIAS, D.C.F.S.; ALVARENGA, E.M.; SOUZA, B.L. Test of exudates color hues for evaluating the physiological potential of coffee (Coffea arabica L.) seeds. Revista Brasileira de Sementes, v. 34, n. 2, p.212-217, 2012. http://www.scielo.br/scielo.php?pid=S010131222012000200004\&script=sci_arttext
MALTA, M.R.; PEREIRA, R.G.F.A.; CHAGAS, S.J.R. Condutividade elétrica e lixiviação de potássio do exsudato de grãos de café: alguns fatores que podem influenciar essas avaliações. Ciência e Agrotecnologia, v.29, n.5, p.1015-1020, 2005. http://www.scielo.br/scielo.php?pid=S1413$70542005000500015 \&$ script $=$ sci_arttext

MARCOS-FILHO, J. Fisiologia de sementes de plantas cultivadas. Piracicaba: FEALQ, 2015a. 659p.

MARCOS-FILHO, J. Seed vigor testing: an overview of the past, present and future perspective. Scientia Agricola, v.72, n.4, p.363-374, 2015b. http:// www.revistas.usp.br/sa/article/viewFile/100211/98873

MILOSEVIC, M.; VUJAKOVIK, M.; KARAGIC, D. Vigor tests as indicators of seed viability. Genetika, v.42, n.1, p.103-118, 2010. http://www. doiserbia.nb.rs/img/doi/0534-0012/2010/0534-00121001103M.pdf

REIS, L.S.; ARAÚJO, E.F.; DIAS, D.C.F.S.; SEDIYAMA, C.S.; MEIRELES, R.C. LERCAFÉ: novo teste para estimar o potencial germinativo de sementes de cafeeiro (Coffea arabica L.). Revista Brasileira de Sementes, v.32, n.1, p.009-016, 2010. http://www.scielo.br/scielo. php? script $=$ sci_arttext\&pid $=$ S0101-31222010000100001\&lng $=$ pt\&nrm $=\mathrm{i}$ so

SERA, G.H.; MIGLIORANZA, E. Avaliação visual do poder germinativo de sementes de café por exsudatos. In: Simpósio de Pesquisas dos Cafés do Brasil. 2000. Poços de Caldas-MG. Brasilia, 2000. v.1, p.123-125. http:// www.sbicafe.ufv.br/handle/123456789/870

SERA, G.H.; MIGLIORANZA, E.; SERA, T. Avaliação da viabilidade de sementes de café por exsudatos. Semina: Ciências Agrárias, v.27, n.1, p.2126, 2006. http://www.uel.br/revistas/wrevojs246/index.php/semagrarias/ article/view/2395

SOTO, F.; ECHEVARRIA, I.; RODRIGUEZ, P. Estudio sobre la conservacion de semillas de cafetos (Coffea arabica L. variedad Caturra). Cultivos Tropicales, v.16, n.1, p.33-36, 1995. http://www.sidalc.net/cgi-bin/wxis.exe/?IsisScript=CAFE.xis\&method $=$ post\& formato $=2 \&$ cantidad $=1$ \& expresion $=\mathrm{mfn}=005796$

VIEIRA, M.G.G.C.; GUIMARÃES, R.M.; PINHO, E.V.R.V.; GUIMARÃES, R.J.; OLIVEIRA, J.A. Testes rápidos para determinação da viabilidade e da incidência de danos mecânicos em sementes de cafeeiro. Lavras: UFLA, 1998. 34p. (Boletim Agropecuário, 26).

ZONTA, J.B.; ARAÚJO, E.F.; ARAÚJO, R.F.; REIS, M.S. Uso do teste Lercafé para a caracterização de danos em sementes de cafeeiro. Pesquisa Agropecuária Brasileira, v.43, n.11, p.1601-1607, 2008. http://www.scielo. br/scielo.php?pid=S0100-204X2008001100020\&script=sci_arttext 